\title{
The relationship between problematic cell phone use, eating disorders and social anxiety among university students
}

\author{
Ayse Gokce ${ }^{1}$, Ali Ozer ${ }^{2}$
}

\begin{abstract}
Objective: Problematic cell phone use is common among young age groups which include university students, and may be accompanied by social anxiety and eating disorders. We aimed to examine the relationship between problematic cell phone use, social anxiety and eating disorders among university students.

Methods: The universe of this cross-sectional study consists of 28,669 students receiving education at a Inonu University between October 2017 - November 2017. With a confidence interval of $95 \%$ and power of $80 \%$, the sample size was calculated to be 308 . The survey forms used in the study included students' sociodemographic characteristics, data regarding cell phone usage, Problematic Mobile Phone Use Scale, Liebowitz Social Anxiety Scale and Eating Attitudes Test. The statistical analyses were conducted using Student t, One Way ANOVA, Spearman Correlation Test and Binomial Logistic Regression Analysis.

Results: The students in the study group demonstrated a $46.1 \%$ rate of problematic cell phone use. The students' Problematic Mobile Phone Use Scale total scores showed a significant correlation with smoking, and daily duration and purpose of cell phone use $(p<0.05)$.

Conclusion: University students demonstrate high rates of problematic cell phone use; in addition, individuals who use cell phones for increased hours or for certain purposes display higher total scores on the Problematic Mobile Phone Use Scale. Students should be educated on limiting problematic cell phone use.
\end{abstract}

KEYWORDS: Eating disorders, Problematic cell phone use, Students, Social anxiety.

doi: https://doi.org/10.12669/pjms.37.4.4124

How to cite this:

Gokce A, Ozer A. The relationship between problematic cell phone use, eating disorders and social anxiety among university students. Pak J Med Sci. 2021;37(4):1201-1205. doi: https://doi.org/10.12669/pjms.37.4.4124

This is an Open Access article distributed under the terms of the Creative Commons Attribution License (http://creativecommons.org/licenses/by/3.0), which permits unrestricted use, distribution, and reproduction in any medium, provided the original work is properly cited.

1. Dr. Ayse Gokce

Bingol Provincial Health Directorate,

Bingol, Turkey.

2. Dr. Ali Ozer

Department of Public Health, Inonu University,

Faculty of Medicine,

Malatya Turkey.

Correspondence:

Dr. Ayse Gokce,

Specialist Doctor,

Bingol Provincial Health Directorate,

Yenisehir District,

Guldiken Street No: 11,

Bingol, Turkey.

Email: abaran88@hotmail.com

* Received for Publication:

* Revision Received:

* Accepted for Publication:
January 5, 2021

January 22, 2021

March 28, 2021

\section{INTRODUCTION}

Due to the rapid advancement in technology throughout the prior years, cell phones have become essential for daily tasks both in our country and around the world. The use of cell phones has become embedded in daily life as they offer numerous benefits for daily efficiency; however, they can be harmful and result in potentially disturbing behaviors, some in which the mechanism of action is not yet clear. According to the 2018 report of the Turkish Statistical Institute (TSI), $97.8 \%$ of households contained smartphones in the year 2017, with this rate reaching $98.7 \%$ in 2018. ${ }^{1}$ There are very few households that do not 
contain a smartphone. Besides being appealing and user-friendly, smartphones can be detrimental for the user if used compulsively or problematically. In light of previous studies, it is said that cell phone addiction and problematic cell phone use have a strong correlation and similar concepts are used interchangeably in the literature. ${ }^{2,3}$

Problematic cell phone use is defined as the inability of an individual to limit their cell phone use despite the detrimental effects it increases. ${ }^{4}$ Many studies have reported the widespread problematic cell phone use among university students to be an increasingly significant public health concern that causes a decline in the functionality of students due to addiction. In addition, the relationship between problematic cell phone use and social anxiety has been examined in several studies. However, there are limited studies on the correlation between problematic use, social anxiety and eating disorders. The goal of this study was to examine problematic cell phone use and its relationship with social anxiety and eating disorders among university students.

\section{METHODS}

This cross-sectional study was conducted between October 2017 - November 2017 with written permission from the Scientific Research and Publication Ethics Committee (2017 \24-11) of Inonu University and the Inonu University Rectorate. The study included students receiving education at Inonu University who were over the age of 18 and agreed to participate. The study universe includes 28669 students. With a confidence interval of $95 \%$ and power of $80 \%$, the sample size was calculated to be 308 on the basis of a $28.2 \%$ problematic cell phone use rate in the reference study. ${ }^{5}$ The students were first categorized according to their educational faculty and participants from every faculty were then picked using the simple random sampling method. A face-to-face survey was conducted with 104 males and 215 females for a total of 319 people.

The survey form used in the study consisted of four sections. The first section included the students' sociodemographic characteristics and data regarding cell phone use; the second section consisted of the Problematic Mobile Phone Use Scale (PU); the third section included the Liebowitz Social Anxiety Scale (LSAS); the last section involved the Eating Attitudes Test (EAT).

Statistical methods: Software programs used for the statistical analysis of data were SPSS 22.0 and "biostatapps", an artificial intelligence and statistics based interactive web program. ${ }^{6}$ The dependent variables of the study are scores from the PU, LSAS, and EAT, while the independent variables include age, gender, socioeconomic status, place of residence, current residence, and duration of cell phone use. Student t, One Way ANOVA, Spearman Correlation Test and Binomial Logistic Regression Analysis were utilized in the statistical analysis of data and $\mathrm{p}<0.05$ was considered significant in all evaluations.

\section{RESULTS}

The age range of the participating students was $18-33$, and their age mean is $21.03 \pm 2.05$. Table-I displays the sociodemographic distribution of the students participating in the study.

The average daily duration of cell phone use in the study group: $21.6 \%$ three hours or less, $31.7 \%$ between 4-5 hours, $18.5 \%$ between 6-7 hours, and $28.2 \%$ longer than eight hours. When asked for their purpose of cell phone use, the students stated that: $55.5 \%$ use it to access social media platforms such as Facebook and Twitter, 31.7\% use it for WhatsApp, $22.9 \%$ for phone calls, $15.7 \%$ for SMS messaging, and $11.3 \%$ for playing mobile games.

Table-I: Sociodemographic Distribution of Students Participating in the Study.

\begin{tabular}{lcc}
\hline Sociodemographic Characteristics & $n$ & $\%$ \\
\hline Gender & & \\
Male & 215 & 32.6 \\
Female & 67.4 \\
Faculty & 72 & 22.6 \\
Health Sciences & 156 & 48.9 \\
Social Sciences & 91 & 28.5 \\
Science & & \\
Current Residence & 106 & 33.2 \\
Government/Private Dormitory & 45 & 14.1 \\
House with Friends/Alone & 168 & 52.7 \\
Family Home & & \\
Region of Longest Residence in Lifetime & \\
City & 231 & 72.4 \\
District/Village & 88 & 27.6 \\
Total & 319 & 100 \\
\hline
\end{tabular}


Relationship between problematic cell phone use, eating disorders \& social anxiety

Table-II: Comparison of the Students' Total PU Scores with Respect to Various Variables

\begin{tabular}{|c|c|c|}
\hline Variables & PU Total Score & $p$ \\
\hline \multicolumn{3}{|c|}{ Average Duration of Daily Cell Phone Use } \\
\hline$\leq 3$ hours & $29.11 \pm 11.64$ & \multirow{4}{*}{$0.0001^{*}$} \\
\hline 4-5 hours & $33.93 \pm 12.31$ & \\
\hline 6-7 hours & $38.42 \pm 11.68$ & \\
\hline$\geq 8$ hours & $42.53 \pm 13.08$ & \\
\hline \multicolumn{3}{|c|}{ Cigarette Use } \\
\hline Yes & $39.17 \pm 14.84$ & \multirow[t]{2}{*}{$0.024^{* *}$} \\
\hline No & $35.24 \pm 12.41$ & \\
\hline \multicolumn{3}{|l|}{ Alcohol Use } \\
\hline Yes & $38.86 \pm 14.20$ & \multirow[t]{2}{*}{$0.098^{* *}$} \\
\hline No & $35.60 \pm 12.81$ & \\
\hline \multicolumn{3}{|c|}{ Purpose of Cell Phone Use is to Access Social Media Platforms such as Facebook/Twitter } \\
\hline Yes & $37.60 \pm 13.03$ & \multirow[t]{2}{*}{$0.026^{* *}$} \\
\hline No & $34.32 \pm 12.97$ & \\
\hline \multicolumn{3}{|c|}{ Purpose of Cell Phone Use is WhatsApp } \\
\hline Yes & $36.75 \pm 12.24$ & \multirow[t]{2}{*}{$0.374^{* *}$} \\
\hline No & $35.44 \pm 14.00$ & \\
\hline \multicolumn{3}{|c|}{ Purpose of Cell Phone Use is Phone Calls } \\
\hline Yes & $34.44 \pm 12.12$ & \multirow[t]{2}{*}{$0.114^{* *}$} \\
\hline No & $36.93 \pm 13.46$ & \\
\hline \multicolumn{3}{|c|}{ Purpose of Cell Phone Use is Mobile Gaming } \\
\hline Yes & $40.19 \pm 13.45$ & \multirow[t]{2}{*}{$0.049^{* *}$} \\
\hline No & $39.63 \pm 12.97$ & \\
\hline
\end{tabular}

*One Way ANOVA ** Student T Test.

Students who used their cell phones for a longer duration scored significantly higher PU scores $(p=0.0001)$. In the comparison of total PU scores according to purpose of cell phone use; students who use their phone to access social media platforms such as Facebook/Twitter or to play mobile games scored significantly higher compared to those who did not $(\mathrm{p}<0.05)$.

The results of the regression test in which the presence of problematic cell phone use in students was assessed with respect to faculty, region of longest residence in lifetime, and presence of an eating disorder or social anxiety is shown in Table-III. Problematic cell phone use was 2.09 times more common in students who spent most of their lifetime in a district or village compared to those who spent it in a city. According to TableIV, there is a mild, significant, positive correlation between the PU and LSAS scores of the students participating in the study $(\mathrm{p}=0.001 ; \mathrm{r}=00187)$.
Table-III: Binomial Logistic Regression Analysis of Independent Variables Associated with the Presence of Problematic Cell Phone Use.

\begin{tabular}{lccc}
\hline & OR & $95 \% \mathrm{Cl}$ & $p$ \\
\hline $\begin{array}{l}\text { Faculty } \\
\text { Health Sciences }\end{array}$ & 1 & & \\
Social Sciences/Sciences & 1.095 & $0.607-1.976$ & 0.224 \\
Region of Longest Residence in Lifetime & & \\
City & 1 & & \\
District/Village & 2.092 & $1.245-3.548$ & 0.006 \\
Eating Behavior Disorder & & & \\
Not present & 1 & & \\
Present & 1.535 & $0.785-3.04$ & 0.212 \\
Presence of Social Anxiety & & & \\
Not present & 1 & & \\
Present & 1.427 & $0.785-3.04$ & 0.212 \\
\hline
\end{tabular}


Table-IV: Comparison of PU LSAS and EAT Scores of the Students Participating in the Study.

\begin{tabular}{ccc}
\hline & LSAS Score & EAT Score \\
\hline PU Score & & \\
$\mathrm{r}$ & 0.187 & 0.092 \\
$\mathrm{p}$ & 0.001 & 0.100 \\
LSAS Score & & \\
$\mathrm{r}$ & 1.00 & 0.261 \\
$\mathrm{p}$ & - & 0.0001 \\
\hline
\end{tabular}

\section{DISCUSSION}

Twenty-eight-point two percent of students stated that their cell phone usage was eight hours or more. In a 2013 study done with students from a faculty of education, it was found that $34.3 \%$ of students used their cell phones for three hours or more daily. ${ }^{7}$ Alongside the fact that the duration of cell phone use is associated with problematic use and addiction, it has been observed that application-oriented use is also significant in leading to problematic use. ${ }^{8,9}$ The fact that $28 \%$ of the students in our study use their cell phones for eight hours or more may reveal risks associated with problematic use and cell phone addiction.

The rate of problematic cell phone use in the study group students is $46.1 \%$. In the literature, several studies have reported problematic cell phone use rates between $20.1-48.7 \% .^{10-13}$ A study comparing problematic cell phone use between age groups found that the 16-25 age group had the highest rate of problematic use..$^{14}$ The rate of problematic cell phone use can vary according to the age group, gender ratio and sociocultural differences of the population participating in the study.

In the comparison of PU scores according to cell phone use duration, students who used their phones for a longer duration exhibited significantly higher PU scores. Similar studies have found that the longer the use of mobile phones, the more risk of mobile phone addiction and problematic use are. ${ }^{15,16}$ Since the duration of cell phone use induces addiction and problematic use, it is believed that most students in the study group face this risk.

The PU scores of students in the study were significantly higher in smokers compared to nonsmokers. While some studies found that smokers exhibited significantly higher rates of cell phone addiction, others did not find a significant relationship between smoking status and cell phone addiction. ${ }^{15,16}$

In the comparison of total PU scores according to cell phone use purpose; it was found that students using their phones to access social media platforms such as Facebook/Twitter or playing mobile games had significantly higher scores compared to those who did not. Previous study has shown that individuals who use smartphones with SMS and mobile internet features are highly susceptible to mobile addiction and severe symptoms as a result of this addiction compared to those who do not use these smartphones. ${ }^{17}$ In a 2013 study it was found that using cell phone communication methods such as messaging, social media, and e-mail lead to higher rates of problematic use. ${ }^{18}$ Although there may be studies among various populations, most students today use their cell phones to access the internet and social media platforms. This application-oriented use may increase the rate of problematic use.

In the study group, students who had spent most of their lifetime in a district or village demonstrated 2.09 times more problematic use of cell phones compared to students who spent it in a city. Students living in rural areas have limited access to recreational activities such as the cinema, theater and social facilities that they can attend in their leisure time; as a result, they may spend their free time on their cell phones and display higher rates of problematic use.

There is a mild, significant, positive correlation between the PU and LSAS scores of the students participating in the study. Similar to the results of our research, a study conducted in our country's university showed a positive correlation between problematic internet use, loneliness and anxiety levels. ${ }^{16}$ Moreover, there are studies showing that individuals who use their cell phones problematically frequently exhibit psychological problems such as depression, anxiety and decreased life satisfaction. ${ }^{19,20}$ Studies in the literature whose topics are similar to that of our research have reported similar results.

No significant relationship was found between the PU and EAT scores in the study group. Although no study in the literature has examined the relationship between the eating attitude test and cell phone addiction or problematic use of cell phones, there are studies analyzing its relationship with internet addiction. In our country, a study conducted in 2014 found no significant correlation 
between the EAT and internet addiction, similar to our study; however, the study reported a significant positive correlation between body mass index and internet addiction. ${ }^{21} \mathrm{~A}$ cohort study conducted in China with 1252 high school and university participants reported that females with internet addiction demonstrated significantly higher eating attitude test scores compared to females without addiction. ${ }^{22}$ Since an increase in body mass index is certainly an indication of obesity or high body weight, an increase in the problematic use of cell phone score may be associated with an increase in body mass index.

In addition to the detrimental effects of problematic use alone, mobile phones carry significance because they can contribute to the occurrence of social anxiety and eating disorders, as was also found in our study. Young university students should be encouraged to join social communities so that they may take a break from technology and spend their leisure time developing meaningful relationships. Thus, the young individual who begins contributing to the community can be more integrated with society and limit his/her mobile phone use, where he/she alleviates social loneliness.

Acknowledgements: We would like to thank all of the students who participated in this research.

Grant Support and Financial Disclosures: None.

\section{REFERENCES}

1. Turkish Statistical Institute (TSI). Statistics on Family, 2018 https:/ / data.tuik.gov.tr/Bulten/Index?p=IstatistiklerleAile-2018-30726 Accessed Date: 10.08.2019.

2. Hong FY, Chiu SI, Huang DH. A model of the relationship between psychological characteristics, mobile phone addiction and use of mobile phones by Taiwanese university female students. Comput Hum Behav. 2012;28(6):2152-2159. doi: 10.1016/j.chb.2012.06.020

3. Ahmed I, Qazi TF. A look out for academic impacts of Social networking sites (SNSs): A student based perspective. Afr J Bus Manag. 2011;5(12):5022-5031. doi: 10etik.5897/AJBM11.595

4. Billieux J. Problematic use of the mobile phone: a literature review and a pathways model. Curr Psy Rev. 2011;8(4):299-307. doi: $10.2174 / 157340012803520522$

5. Tao S, Wu X, Zhang Y, Zhang S, Tong S, Tao F. Effects of sleep quality on the association between problematic mobile phone use and mental health symptoms in Chinese college students. Int J Environ Res Public Health. 2017;14(2):185. doi: 10.3390/ijerph14020185

6. Arslan AK, Yasar S, Colak C, Yologlu S. An Interactive Web Application for Kruskal Wallis Test with R Shiny. Inonu Universitesi Saglik Bilimleri Dergisi. 2018;7(2):49-55.

7. Unal AT, Arslan A. Comparison of cell phone usage frequencies and brand preferences of public and private university education faculty students. Gaziantep Univ J Soc Sci. 2013;12(1):1-19. doi: 10.21547/jss.766890
8. Roberts J, Yaya L, Manolis C. The invisible addiction: Cell-phone activities and addiction among male and female college students. J Behav Addict. 2014;4:254-265. doi: 10.1556/jba.3.2014.015

9. Tossell C, Kortum P, Shepard C, Rahmati A, Zhong, L. Exploring smartphone addiction: insights from long-term telemetric behavioral measures. Int J Interact Mobile Tech. 2015;9(2):1-7. doi: 10.3991/ijim.v9i2.4300

10. Tekin C, Gunes G, Colak C. Adaptation of problematic mobile phone use scale to Turkish: A validity and reliability study. Med Sci. 2014;3(3):1361. doi: 10.5455/medscience.2014.03.8138

11. Lopez-Fernandez O, Honrubia-Serrano ML, Freixa-Blanxart M. Spanish adaptation of the "Mobile Phone Problem Use Scale" for adolescent population. Adicciones. 2012;24(2):123-130.

12. Lopez-Fernandez O, Honrubia-Serrano L, Freixa-Blanxart M, Gibson W. Prevalence of problematic mobile phone use in British adolescents. Cyberpsych Beh Soc N. 2014;17(2):91-98. doi: 10.1089 /cyber.2012.0260

13. Mohammadi Kalhori S, Mohammadi MR, Alavi SS, Jannatifard F, Sepahbodi G, Reisi MB, et al. Validation and Psychometric Properties of Mobile Phone Problematic Use Scale (MPPUS) in university students of Tehran. Iran J Psych. 2015;10(1):25-31.

14. De-Sola J, Talledo H, Rodríguez de Fonseca F, Rubio G. Prevalence of problematic cell phone use in an adult population in Spain as assessed by the Mobile Phone Problem Use Scale (MPPUS). Plos One. 2017;12(8):e0181184. doi: 10.1371/journal. pone. 0181184

15. Sahin S, Ozdemir K, Unsal A, Temiz N. Evaluation of mobile phone addiction level and sleep quality in university students. Pak J Med Sci. 2013;29(4):913-918. doi: 10.12669/pjms.294.3686

16. Odaci $\mathrm{H}$, Kalkan M. Problematic Internet use, loneliness and dating anxiety among young adult university students. Comput Edu. 2010;55(3):1091-1097. doi: 10.1016/j.compedu.2010.05.006

17. Lin TT, Chiang Y-H, Jiang Q. Sociable people beware? Investigating smartphone versus nonsmartphone dependency symptoms among young Singaporeans. Soc Behav Personal. 2015;43(7):1209-1216. doi: 10.2224/sbp.2015.43.7.1209

18. Takao M. Problematic mobile phone use and big-five personality domains. Indian J Comm Med. 2014;39(2):111-113.

19. Lepp A, Barkley JE, Karpinski AC. The relationship between cell phone use, academic performance, anxiety, and satisfaction with life in college students. Comput Hum Behav. 2014;31:343-350. doi: 10.1016/j.chb.2013.10.049

20. Elhai JD, Dvorak RD, Levine JC, Hall BJ. Problematic smartphone use: A conceptual overview and systematic review of relations with anxiety and depression psychopathology. J Affec Disord. 2017;207:251-259. doi: 10.1016/j.jad.2016.08.030

21. Canan F, Yildirim O, Ustunel TY, Sinani G, Kaleli AH, Gunes $C$ et al. The relationship between internet addiction and body mass index in Turkish adolescents. Cyberpsych Beh. 2014;17(1):40-45. doi: 10.1089/cyber.2012.0733

22. Celik S, Ugur BA, Aykurt FA, Bektas M. Eating attitudes and related factors in Turkish nursing students. Nurs Midwifery Stud. 2015;4(2):e25479. doi: 10.17795/nmsjournal25479

\section{Authors' Contribution:}

AG; designed, did data collection, manuscript writing, final approval of manuscript.

AO; did statistical analysis, manuscript writing and editing manuscript. 